\title{
Actinophytocola timorensis sp. nov. and Actinophytocola corallina sp. nov., isolated from soil
}

\author{
Correspondence \\ Misa Otoguro \\ otoguro-misa@nite.go.jp
}

\author{
Misa Otoguro, ${ }^{1}$ Hideki Yamamura, ${ }^{1,2}$ Tomohiko Tamura, ${ }^{1}$ \\ Rohmatussolihat Irzaldi, ${ }^{3}$ Shanti Ratnakomala, ${ }^{3}$ Roni Ridwan, ${ }^{3}$ \\ Gina Kartina, ${ }^{3}$ Evi Triana, ${ }^{4}$ Arif Nurkanto, ${ }^{4}$ Yulin Lestari, ${ }^{5}$ \\ Puspita Lisdiyanti, ${ }^{3}$ Yantyati Widyastuti ${ }^{3}$ and Katsuhiko Ando ${ }^{1}$
}

${ }^{1}$ NITE Biological Resource Center (NBRC), Department of Biotechnology, National Institute of Technology and Evaluation (NITE), 2-5-8 Kazusakamatari, Kisarazu, Chiba 292-0818, Japan

${ }^{2}$ Division of Applied Biological Sciences, Interdisciplinary Graduate School of Medicine and Engineering, University of Yamanashi, 4-3-11 Takeda, Kofu 400-8511, Japan

${ }^{3}$ Research Center for Biotechnology, Indonesian Institute of Sciences, Jl. Raya Bogor Km. 46, Cibinong 16911, Indonesia

${ }^{4}$ Research Center for Biology, Indonesian Institute of Sciences, Jl. Raya Bogor Km. 46, Cibinong 16911, Indonesia

${ }^{5}$ Department of Biology, Faculty of Mathematics and Natural Science, Bogor Agricultural University, J. Raya pajajaran, Bogor 16144, Indonesia

Two actinomycete strains, ID05-A0653 ${ }^{\top}$ and ID06-A0464 ${ }^{\top}$, were isolated from soils of West Timor and Lombok island, respectively, in Indonesia. 16S rRNA gene sequence analysis clearly demonstrated that the isolates belonged to the family Pseudonocardiaceae and were closely related to the genus Actinophytocola. Strains ID05-A0653 ${ }^{\top}$ and ID06-A0464 ${ }^{\top}$ exhibited 98.1 and 98.2\% 16S rRNA gene sequence similarity, respectively, with Actinophytocola oryzae GMKU $367^{\top}$. The isolates grew well on ISP media and produced white aerial mycelium. Short spore chains were formed directly on the substrate mycelium. The isolates contained mesodiaminopimelic acid, arabinose and galactose as cell-wall components, MK-9 $\left(\mathrm{H}_{4}\right)$ as the sole isoprenoid quinone, iso- $\mathrm{C}_{16: 0}$ as the major cellular fatty acid and phosphatidylethanolamine as the diagnostic polar lipid. The DNA G $+\mathrm{C}$ contents of strains ID05-A0653 ${ }^{\top}$ and ID06-A0464 ${ }^{\top}$ were 69.7 and $71.2 \mathrm{~mol} \%$, respectively. On the basis of phenotypic characteristics, DNA-DNA relatedness and $16 \mathrm{~S}$ rRNA gene sequence comparisons, strains ID05-A0653 ${ }^{\top}$ and ID06-A0464 ${ }^{\top}$ each represent a novel species of the genus Actinophytocola, for which the names Actinophytocola timorensis sp. nov. (type strain ID05-A0653 ${ }^{\top}=\mathrm{BTCC} \mathrm{B-673^{ \top }}=\mathrm{NBRC}$ $105524^{\top}$ ) and Actinophytocola corallina sp. nov. (type strain ID06-A0464 ${ }^{\top}=$ BTCC B-674 $=$ NBRC $105525^{\top}$ ) are proposed.

The family Pseudonocardiaceae was originally proposed by Embley et al. (1988) for mycolateless cell-wall chemotype IV actinomycetes. The description of the family was later emended by Zhi et al. (2009) on the basis of 16S rRNA gene sequence analysis. The family currently includes the genera Actinoalloteichus (Tamura et al., 2000), Actinomycetospora

The GenBank/EMBL/DDBJ accession numbers for the 16S rRNA gene sequences of strains ID05-A0653 ${ }^{\top}$ and ID06-A0464 ${ }^{\top}$ are AB511315 and $A B 511316$, respectively.

A supplementary figure and a supplementary table are available with the online version of this paper.
(Jiang et al., 2008), Allokutzneria (Labeda \& Kroppenstedt, 2008), Amycolatopsis (Lechevalier et al., 1986), Crossiella (Labeda, 2001), Goodfellowiella (Labeda \& Kroppenstedt, 2006; Labeda et al., 2008), Kibdelosporangium (Shearer et al., 1986), Kutzneria (Stackebrandt et al., 1994), Prauserella (Kim \& Goodfellow, 1999), Pseudonocardia (Henssen, 1957), Saccharomonospora (Nonomura \& Ohara, 1971), Saccharopolyspora (Lacey \& Goodfellow, 1975), Sciscionella (Tian et al., 2009), Streptoalloteichus (Tomita et al., 1987), Thermobispora (Wang et al., 1996) and Thermocrispum (Korn-Wendisch et al., 1995). Recently, the genus Actinophytocola (Indananda et al., 2010) has been added to the 
family; its first species was isolated from the roots of Thai glutinous rice plants. Genera of the family Pseudonocardiaceae are distinguishable from each other on the basis of morphological, chemotaxonomic and a few physiological characteristics and they form a distinct group on the basis of $16 \mathrm{~S}$ rRNA gene sequence analysis. During an investigation of actinomycetes recovered from Indonesia, strains ID05A $0653^{\mathrm{T}}$ and ID06-A0464 ${ }^{\mathrm{T}}$ were isolated from soil samples collected at West Timor and Lombok island, respectively. These two strains showed chemotaxonomic characteristics of the family Pseudonocardiaceae and morphological and chemotaxonomic characteristics of the genus Actinophytocola but were genotypically and phenotypically distinguishable from members of recognized Actinophytocola species.

Strains ID05-A0653 ${ }^{\mathrm{T}}$ and ID06-A0464 ${ }^{\mathrm{T}}$ were isolated on humic acid-vitamin (HV) agar (Hayakawa \& Nonomura, 1987), using the SDS/yeast extract method (Hayakawa \& Nonomura, 1989) and the rehydration and centrifugation method (Hayakawa et al., 2000), respectively. The isolates were maintained on yeast extract-malt extract agar (ISP 2) and stored as glycerol suspensions $(20 \%, \mathrm{v} / \mathrm{v})$ at $-80{ }^{\circ} \mathrm{C}$. Cell morphology of cultures grown on HV agar or NBRC medium 266 (yeast extract-starch agar) at $28{ }^{\circ} \mathrm{C}$ for 14 21 days was observed using light microscopy and scanning electron microscopy (model JSM-6060; JEOL). Cultural and physiological properties were characterized using several well-established procedures (Gordon et al., 1974; Shirling \& Gottlieb, 1966) and API tests (bioMérieux). For cultural characterization, the isolates were grown at $28{ }^{\circ} \mathrm{C}$ for 21 days on a series of ISP media, NBRC medium 266 and NBRC medium 231 (maltose-Bennett's agar). The colour of colonies was determined according to Rayner (1970). Growth with $0-6 \% \mathrm{NaCl}$ and the temperature range for growth were investigated using NBRC medium 266 for 21 days. Growth at $\mathrm{pH} 3.0-9.0$ was determined using yeast extract-glucose broth.

Strains ID05-A0653 ${ }^{\mathrm{T}}$ and ID06-A0464 ${ }^{\mathrm{T}}$ formed a branched substrate mycelium, which fragmented into rod-shaped elements $(0.5-0.8 \times 0.8-1.2 \mu \mathrm{m})$, and relatively short aerial hyphae with chains of spores (Supplementary Fig. S1, available in IJSEM Online). Short spore chains were formed directly on the substrate mycelium (Supplementary Fig. S1). The isolates grew well on ISP 2, 3, 4, 5 and 7 and NBRC medium 266, and a white to yellowish-white aerial mycelium was observed on ISP 5 and 7 and NBRC medium 266. Strain ID05-A $0653^{\mathrm{T}}$ produced moderate orange-yellow soluble pigment and ID06-A0464 ${ }^{\mathrm{T}}$ produced coral soluble pigment on ISP 7 . The isolates utilized glucose, D-fructose, lactose, maltose, D-mannitol, raffinose, rhamnose and trehalose as sole carbon sources. Additionally, strain ID05A $0653^{\mathrm{T}}$ used adonitol, sucrose and xylose and strain ID06A0464 ${ }^{\mathrm{T}}$ used D-sorbitol. Strain ID05-A0653 ${ }^{\mathrm{T}}$ grew at $15-$ $37^{\circ} \mathrm{C}$ and strain ID06-A0464 ${ }^{\mathrm{T}}$ grew at $15-28{ }^{\circ} \mathrm{C}$ (Table 1). Other phenotypic characteristics are given in Table 1 and the species descriptions.
Table 1. Phenotypic properties that distinguish strains ID05A0653 ${ }^{\top}$ and ID06-A0464 ${ }^{\top}$ from their closest phylogenetic neighbour

Strains: 1 , A. timorensis sp. nov. ID05-A0653 ${ }^{\mathrm{T}} ; 2$, A. corallina sp. nov. ID06-A0464 ${ }^{\mathrm{T}} ; 3$, A. oryzae NBRC $105245^{\mathrm{T}}$. Data were taken from this study and Indananda et al. (2010). None of the strains grow with $6 \%$ $\mathrm{NaCl}$. +, Positive; - , negative; ND, no data available.

\begin{tabular}{|lccc|}
\hline Characteristic & $\mathbf{1}$ & $\mathbf{2}$ & $\mathbf{3}$ \\
\hline $\begin{array}{l}\text { Nitrate reduction } \\
\text { Use of sole carbon }\end{array}$ & + & - & - \\
sources & & & \\
$\quad$ Adonitol & + & - & ND \\
D-Sorbitol & - & + & - \\
Sucrose & + & - & - \\
D-Xylose & + & - & - \\
Growth with/at: & & & \\
$4 \%$ NaCl & - & + & - \\
$5 \%$ NaCl & - & + & - \\
$37{ }^{\circ} \mathrm{C}$ & + & - & - \\
pH 5 & + & - & + \\
Soluble pigment & Orange-yellow (44) & Coral (38) & None \\
on ISP 7 & & & \\
\hline
\end{tabular}

*Values in parentheses correspond to colour codes from Rayner (1970).

Diaminopimelic acid isomers and sugars of whole-cell hydrolysates were analysed using procedures described by Hasegawa et al. (1983) and Schaal (1985), respectively. Polar lipids were extracted, examined by two-dimensional TLC and identified using methods described by Minnikin et al. (1984). Standard procedures were used for the extraction and analysis of mycolic acids (Schaal, 1985) and isoprenoid quinones (Minnikin et al., 1984). Cellular fatty acid composition was determined using the Microbial Identification system (MIDI). Chromosomal DNA from strains was isolated and purified by the method of Saito \& Miura (1963) with a minor modification (Hatano et al., 2003). DNA G $+C$ content was determined by HPLC, as described by Tamura et al. (1994). DNA-DNA hybridization was carried out as described by Kusunoki et al. (1991) using biotinylated DNA.

Whole-cell hydrolysates of the isolates contained mesodiaminopimelic acid, galactose, arabinose and small amounts of rhamnose. The phospholipid profile corresponded to type II and contained phosphatidylethanolamine, diphosphatidylglycerol and ninhydrin-positive phosphoglycolipids (Lechevalier et al., 1977). The predominant menaquinone was MK-9 $\left(\mathrm{H}_{4}\right)(100 \%)$. The major cellular fatty acid was iso- $\mathrm{C}_{16: 0}$ (Supplementary Table $\mathrm{S} 1$ ). The DNA G + C contents of strains ID05-A0653 ${ }^{\mathrm{T}}$ and ID06A0464 ${ }^{\mathrm{T}}$ were 69.7 and $71.2 \mathrm{~mol} \%$, respectively.

The 16S rRNA genes of the isolates were amplified by PCR as described by Tamura \& Hatano (2001) and directly sequenced using an ABI Prism BigDye Terminator cycle 
sequencing kit (Applied Biosystems) and an automatic DNA sequencer (3130 Genetic Analyzer; Applied Biosystems). The almost-complete 16S rRNA gene sequences of strains ID05$\mathrm{A} 0653^{\mathrm{T}}$ and ID06-A0464 ${ }^{\mathrm{T}}$ (1476 nt) were aligned with reference sequences of the family Pseudonocardiaceae available from EMBL/GenBank/DDBJ using CLUSTAL $\mathrm{x}$ (Thompson et al., 1997). Phylogenetic trees were constructed using the neighbour-joining (Saitou \& Nei, 1987), maximum-likelihood (Felsenstein, 1981) and maximumparsimony (Fitch, 1971) algorithms. Tree topologies were evaluated using the bootstrap resampling method with 1000 replicates (Felsenstein, 1981).

The neighbour-joining and maximum-likelihood phylogenetic trees based on 16S rRNA gene sequences showed that strains ID05-A0653 ${ }^{\mathrm{T}}$ and ID06-A0464 ${ }^{\mathrm{T}}$ formed a monophyletic cluster with Actinophytocola oryzae GMKU $367^{\mathrm{T}}$, which was supported by a bootstrap value of $94 \%$ in the neighbour-joining tree (Fig. 1). $16 \mathrm{~S}$ rRNA gene sequence similarity between the isolates was $98.5 \%$. 16S rRNA gene sequence similarity between strain ID05-A0653 ${ }^{\mathrm{T}}$ and $A$. oryzae GMKU $367^{\mathrm{T}}$ was $98.1 \%$ and between strain ID06A $0464^{\mathrm{T}}$ and A. oryzae GMKU $367^{\mathrm{T}}$ was $98.2 \%$. The isolates showed $<95.3 \% 16 \mathrm{~S}$ rRNA gene sequence similarity to other members of the family Pseudonocardiaceae.

DNA-DNA relatedness between the isolates was $15-50 \%$. DNA-DNA relatedness between strain ID05-A0653 ${ }^{\mathrm{T}}$ and A. oryzae NBRC $105245^{\mathrm{T}}$ was $5-7 \%$ and between strain
ID06-A0464 ${ }^{\mathrm{T}}$ and $A$. oryzae NBRC $105245^{\mathrm{T}}$ was $6-7 \%$. These results were well below the $70 \%$ cut-off value recommended for the assignment of bacterial strains to the same genomic species (Wayne et al., 1987). The results of the $16 \mathrm{~S}$ rRNA gene sequence analysis were supported by the DNA-DNA relatedness results.

Thus, on the basis of phylogenetic position, chemotaxonomic data and morphological features, we propose that strains ID05-A0653 ${ }^{\mathrm{T}}$ and ID06-A0464 ${ }^{\mathrm{T}}$ be classified in two novel species in the genus Actinophytocola, for which we propose the names Actinophytocola timorensis sp. nov. and Actinophytocola corallina sp. nov., respectively.

\section{Description of Actinophytocola timorensis sp. nov.}

Actinophytocola timorensis [ti.mo.ren'sis. N.L. fem. adj. timorensis pertaining to (West) Timor, Indonesia, from where the type strain was isolated].

Good growth on several ISP media and produces orangeyellow pigments on ISP 7. Vegetative mycelium is orangeyellow to yellowish white in colour. Nitrate reduction is positive. Leucine aminopeptidase, acid phosphatase, $\beta$ galactosidase, $\alpha$-glucosidase and $N$-acetyl- $\beta$-glucosaminidase are produced. Adonitol, arabinose, cellobiose, fructose, glucose, lactose, maltose, mannitol, raffinose, rhamnose, salicin, sucrose, trehalose and xylose are used as sole carbon sources, but sorbitol is not. Growth occurs at 15-

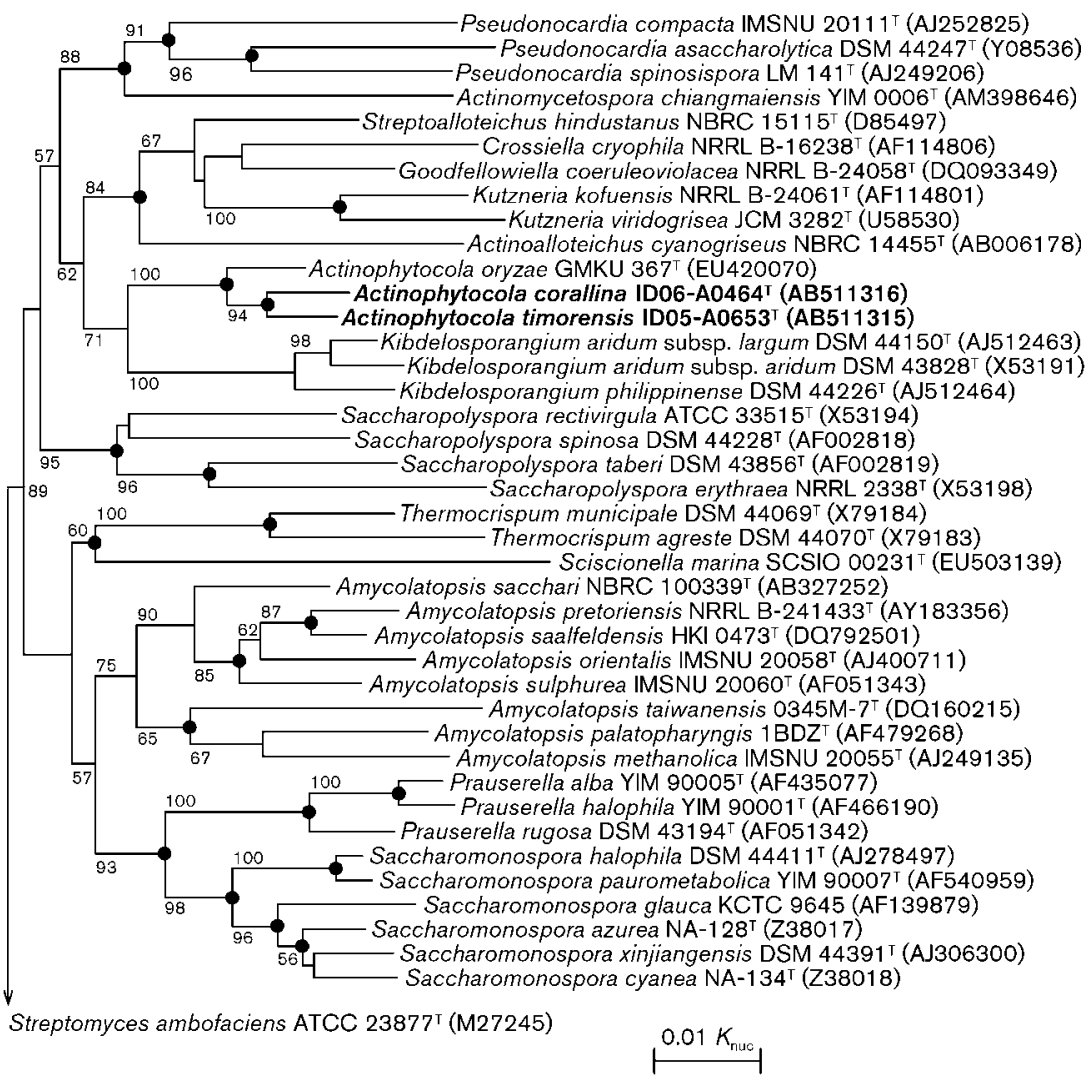

Fig. 1. Neighbour-joining phylogenetic tree based on 16S rRNA gene sequences showing the relationships of strains ID05-A0653 ${ }^{\top}$ and ID06-A0464 ${ }^{\top}$ within the family Pseudonocardiaceae. Bootstrap values $(>50 \%)$ based on 1000 replicates are shown at branch nodes. Filled circles indicate that the corresponding nodes were also recovered in the tree generated with the maximum-likelihood algorithm. Streptomyces ambofaciens ATCC $23877^{\top}$ was used as an outgroup. Bar, $0.01 K_{\text {nuc. }}$. 
$37{ }^{\circ} \mathrm{C}$ (optimum $25-28{ }^{\circ} \mathrm{C}$ ); no growth occurs at $45{ }^{\circ} \mathrm{C}$. No growth with $4 \% \mathrm{NaCl}$. The DNA G $+\mathrm{C}$ content of the type strain is $69.7 \mathrm{~mol} \%$.

The type strain, ID05-A0653 ${ }^{\mathrm{T}}\left(=\mathrm{BTCC}\right.$ B- $673^{\mathrm{T}}=\mathrm{NBRC}$ $105524^{\mathrm{T}}$ ), was isolated from soil of West Timor, Indonesia.

\section{Description of Actinophytocola corallina sp. nov.}

Actinophytocola corallina (co.ral.li'na. L. fem. adj. corallina coral red, because the organism produces coral-coloured soluble pigment).

Good growth on several ISP media and produces coralcoloured pigments on ISP 7. Vegetative mycelium is salmonpink to yellowish-white in colour. Nitrate reduction is negative. Leucine aminopeptidase, acid phosphatase, $\alpha$ glucosidase and $N$-acetyl- $\beta$-glucosaminidase are produced. Arabinose, cellobiose, fructose, glucose, lactose, maltose, mannitol, raffinose, rhamnose, salicin, sorbitol and trehalose are used as sole carbon sources, but sucrose and xylose are not. Growth occurs at $15-28{ }^{\circ} \mathrm{C}$ (optimum $25-28{ }^{\circ} \mathrm{C}$ ); no growth occurs at $37^{\circ} \mathrm{C}$. No growth with $6 \% \mathrm{NaCl}$. The DNA G + C content of the type strain is $71.2 \mathrm{~mol} \%$.

The type strain, ID06-A0464 ${ }^{\mathrm{T}}\left(=\mathrm{BTCC}\right.$ B- $674^{\mathrm{T}}=\mathrm{NBRC}$ $105525^{\mathrm{T}}$ ), was isolated from soil of Lombok island, Indonesia.

\section{Acknowledgements}

This work was conducted under a Joint Research Project between the Department of Biotechnology, National Institute of Technology and Evaluation, Japan, and the Indonesian Institute of Sciences (LIPI) representing Indonesian Government Research Institutes. The authors would like to thank Ms Yayoi Sakiyama for assistance with the chemotaxonomic analyses and Mr Nobuyuki Goto and Ms Ayako Hashimoto for determination of the 16S rRNA gene sequences and DNA-DNA relatedness.

\section{References}

Embley, T. M., Simida, J. \& Stackebrandt, E. (1988). The phylogeny of mycolate-less wall chemotype IV actinomycetes and description of Pseudonocardiaceae fam. nov. Syst Appl Microbiol 11, 44-52.

Felsenstein, J. (1981). Evolutionary trees from DNA sequences: a maximum likelihood approach. J Mol Evol 17, 368-376.

Fitch, W. M. (1971). Toward defining the course of evolution: minimum change for a specific tree topology. Syst Zool 20, 406-416.

Gordon, R. E., Barnett, D. A., Handerhan, J. E. \& Pang, C. H.-N (1974). Nocardia coeliaca, Nocardia autotrophica, and the nocardin strain. Int J Syst Bacteriol 24, 54-63.

Hasegawa, T., Tanida, S., Hatano, K., Higashide, E. \& Yoneda, M. (1983). Motile actinomycetes: Actinosynnema pretiosum subsp. pretiosum sp. nov., subsp. nov., and Actinosynnema pretiosum subsp. auranticum subsp. nov. Int J Syst Bacteriol 33, 314-320.

Hatano, K., Nishii, T. \& Kasai, H. (2003). Taxonomic re-evaluation of whorl-forming Streptomyces (formerly Streptoverticillium) species by using phenotypes, DNA-DNA hybridization and sequences of gyrB, and proposal of Streptomyces luteireticuli (ex Katoh and Arai 1957) corrig., sp. nov., nom. rev. Int J Syst Evol Microbiol 53, 1519-1529.
Hayakawa, M. \& Nonomura, H. (1987). Humic acid-vitamin agar, a new medium for selective isolation of soil actinomycetes. J Ferment Technol 65, 501-509.

Hayakawa, M. \& Nonomura, H. (1989). A new method for the intensive isolation of actinomycetes from soil. Actinomycetologica 3, 95-104.

Hayakawa, M., Otoguro, M., Takeuchi, T., Yamazaki, T. \& limura, Y. (2000). Application of a method incorporating differential centrifugation for selective isolation of motile actinomycetes in soil and plant litter. Antonie van Leeuwenhoek 78, 171-185.

Henssen, A. (1957). [Morphology and systematics of thermophilic actinomycetes]. Arch Mikrobiol 26, 373-414 (in German).

Indananda, C., Matsumoto, A., Inahashi, Y., Takahashi, Y., Duangmal, K. \& Thamchaipenet, A. (2010). Actinophytocola oryzae gen. nov., sp. nov., isolated from the roots of Thai glutinous rice plants, a new member of the family Pseudonocardiaceae. Int J Syst Evol Microbiol 60, 1141-1146.

Jiang, Y., Wiese, J., Tang, S.-K., Xu, L.-H., Imhoff, J. F. \& Jiang, C.-L. (2008). Actinomycetospora chiangmaiensis gen. nov., sp. nov., a new member of the family Pseudonocardiaceae. Int J Syst Evol Microbiol 58, 408-413.

Kim, S. B. \& Goodfellow, M. (1999). Reclassification of Amycolatopsis rugosa Lechevalier et al. 1986 as Prauserella rugosa gen. nov., comb. nov. Int J Syst Bacteriol 49, 507-512.

Korn-Wendisch, F., Rainey, F., Kroppenstedt, R. M., Kempf, A., Majazza, A., Kutzner, H. J. \& Stackebrandt, E. (1995). Thermocrispum gen. nov., a new genus of the order Actinomycetales, and description of Thermocrispum municipale sp. nov. and Thermocrispum agreste sp. nov. Int J Syst Bacteriol 45, 67-77.

Kusunoki, S., Ezaki, T., Tamesada, M., Hatanaka, Y., Asano, K., Hashimoto, Y. \& Yabuuchi, E. (1991). Application of colorimetric microdilution plate hybridization for rapid genetic identification of 22 Mycobacterium species. J Clin Microbiol 29, 1596-1603.

Labeda, D. P. (2001). Crossiella gen. nov., a new genus related to Streptoalloteichus. Int J Syst Evol Microbiol 51, 1575-1579.

Labeda, D. P. \& Kroppenstedt, R. M. (2006). Goodfellowia gen. nov., a new genus of the Pseudonocardineae related to Actinoalloteichus, containing Goodfellowia coeruleoviolacea gen. nov., comb. nov. Int J Syst Evol Microbiol 56, 1203-1207.

Labeda, D. P. \& Kroppenstedt, R. M. (2008). Proposal for the new genus Allokutzneria gen. nov. within the suborder Pseudonocardineae and transfer of Kibdelosporangium albatum Tomita et al. 1993 as Allokutzneria albata comb. nov. Int J Syst Evol Microbiol 58, 14721475.

Labeda, D. P., Kroppenstedt, R. M., Euzéby, J. P. \& Tindall, B. J. (2008). Proposal of Goodfellowiella gen. nov. to replace the illegitimate genus name Goodfellowia Labeda and Kroppenstedt 2006. Int J Syst Evol Microbiol 58, 1047-1048.

Lacey, J. \& Goodfellow, M. (1975). A novel actinomycete from sugarcane bagasse: Saccharopolyspora hirsuta gen. et sp. nov. J Gen Microbiol 88, 75-85.

Lechevalier, M. P., De Bièvre, C. \& Lechevalier, H. (1977). Chemotaxonomy of aerobic actinomycetes: phospholipid composition. Biochem Syst Ecol 5, 249-260.

Lechevalier, M. P., Prauser, H., Labeda, D. P. \& Ruan, J.-S. (1986). Two new genera of nocardioform actinomycetes: Amycolata gen. nov. and Amycolatopsis gen. nov. Int J Syst Bacteriol 36, 29-37.

Minnikin, D. E., O’Donnell, A. G., Goodfellow, M., Alderson, G., Athalye, M., Schaal, A. \& Parlett, J. H. (1984). An integrated procedure for the extraction of bacterial isoprenoid quinones and polar lipids. J Microbiol Methods 2, 233-241. 
Nonomura, H. \& Ohara, Y. (1971). Distribution of actinomycetes in soil. X. New genus and species of monosporic actinomycetes in soil. J Ferment Technol 49, 895-903.

Rayner, R. W. (1970). A Mycological Colour Chart. Kew, UK: Commonwealth Mycological Institute and British Mycological Society.

Saito, H. \& Miura, K. (1963). Preparation of transforming deoxyribonucleic acid by phenol treatment. Biochim Biophys Acta 72, 619629.

Saitou, N. \& Nei, M. (1987). The neighbor-joining method: a new method for reconstructing phylogenetic trees. Mol Biol Evol 4, 406425 .

Schaal, K. P. (1985). Identification of clinically significant actinomycetes and related bacteria using chemical techniques. In Chemical Methods in Bacterial Systematics, pp. 359-381. Edited by M. Goodfellow \& D. E. Minnikin. London: Academic Press.

Shearer, M. C., Colman, P. M., Ferrin, R. M., Nisbet, L. J. \& Nash, C. H. (1986). New genus of the Actinomycetales: Kibdelosporangium aridum gen. nov., sp. nov. Int J Syst Bacteriol 36, 47-54.

Shirling, E. B. \& Gottlieb, D. (1966). Methods for characterization of Streptomyces species. Int J Syst Bacteriol 16, 313-340.

Stackebrandt, E., Kroppenstedt, R. M., Jahnke, K. D., Kemmerling, C. \& Gürtler, H. (1994). Transfer of Streptosporangium viridogriseum (Okuda et al. 1966), Streptosporangium viridogriseum subsp. kofuense (Nonomura and Ohara 1969), and Streptosporangium albidum (Furumai et al. 1968) to Kutzneria gen. nov. as Kutzneria viridogrisea comb. nov., Kutzneria kofuensis comb. nov., and Kutzneria albida comb. nov., respectively, and emendation of the genus Streptosporangium. Int J Syst Bacteriol 44, 265-269.

Tamura, T. \& Hatano, K. (2001). Phylogenetic analysis of the genus Actinoplanes and transfer of Actinoplanes minutisporangius Ruan et al. 1986 and 'Actinoplanes aurantiacus' to Cryptosporangium minutisporangium comb. nov. and Cryptosporangium aurantiacum sp. nov. Int J Syst Evol Microbiol 51, 2119-2125.
Tamura, T., Nakagaito, Y., Nishii, T., Hasegawa, T., Stackebrandt, E. \& Yokota, A. (1994). A new genus of the order Actinomycetales, Couchioplanes gen. nov., with descriptions of Couchioplanes caeruleus (Horan and Brodsky 1986) comb. nov. and Couchioplanes caeruleus subsp. azureus subsp. nov. Int J Syst Bacteriol 44, 193-203.

Tamura, T., Liu, Z., Zhang, Y. \& Hatano, K. (2000). Actinoalloteichus cyanogriseus gen. nov., sp. nov. Int J Syst Evol Microbiol 50, 14351440.

Thompson, J. D., Gibson, T. J., Plewniak, F., Jeanmougin, F. \& Higgins, D. G. (1997). The ClUStal $x$ windows interface: flexible strategies for multiple sequence alignment aided by quality analysis tools. Nucleic Acids Res 25, 4876-4882.

Tian, X.-P., Zhi, X.-Y., Qiu, Y.-Q., Zhang, Y.-O., Tang, S.-K., Xu, L.-H., Zhang, S. \& Li, W.-J. (2009). Sciscionella marina gen. nov., sp. nov., a marine actinomycete isolated from a sediment in the northern South China Sea. Int J Syst Evol Microbiol 59, 222-228.

Tomita, K., Nakakita, Y., Hoshino, Y., Numata, K. \& Kawaguchi, H. (1987). New genus of the Actinomycetales: Streptoalloteichus hindustanus gen. nov., nom. rev.; sp. nov., nom. rev. Int J Syst Bacteriol 37, 211-213.

Wang, Y., Zhang, Z. \& Ruan, J. (1996). A proposal to transfer Microbispora bispora (Lechevalier 1965) to a new genus, Thermobispora gen. nov., as Thermobispora bispora comb. nov. Int $J$ Syst Bacteriol 46, 933-938.

Wayne, L. G., Brenner, D. J., Colwell, R. R., Grimont, P. A. D., Kandler, O., Krichevsky, M. I., Moore, L. H., Moore, W. E. C., Murray, R. G. E. \& other authors (1987). International Committee on Systematic Bacteriology. Report of the ad hoc committee on reconciliation of approaches to bacterial systematics. Int J Syst Bacteriol 37, 463-464.

Zhi, X.-Y., Li, W.-J. \& Stackebrandt, E. (2009). An update of the structure and 16S rRNA gene sequence-based definition of higher ranks of the class Actinobacteria, with the proposal of two new suborders and four new families and emended descriptions of the existing higher taxa. Int J Syst Evol Microbiol 59, 589-608. 